\title{
Shades of endophytic fungi: Exceptional plant inhabitants with de facto therapeutic promises
}

\author{
Syarifah Ab Rashid, Chean Ring Leong, Md Abu Taher, Nur Rifqah Attifah Rosman, Noor Faizah Che \\ Harun, Nurhanis Syafiqah Mohd Nor Hamin, Nur Amiera Syuhada Rozman, Siti Zubaidah Abdullah, \\ Wan Nor Amaliena Wan Ahmad, Woei Yenn Tong* \\ Universiti Kuala Lumpur, Branch Campus Malaysian Institute of Chemical and Bioengineering Technology, Lot 1988, Kawasan \\ Perindustrian Bandar Vendor, Taboh Naning, 78000 Alor Gajah, Melaka, Malaysia
}

Received 14th January 2021 / Accepted 25th August 2021

\begin{abstract}
From the tropics to the arctic, almost all living plants on the earth are resided by endophytic fungi. The microorganism can be found near intercellular or intracellular tissues and cause void adverse symptoms of infection. Endophytes and host plants are synergistically protecting each other. As the host provides nutrients, the endophytes serve the host by activating their defense mode against parasites and pests. A search for alternative drugs, mostly from natural sources, is in ascending trends due to the increase of lethal diseases. This review emphasizes the significance of several endophytic fungi as a foundation for novel bioactive sources which might be advantageous for human health. The communication between the endophytic fungi and their host has generated numerous unique bioactive metabolites from different biosynthetic pathways. These include ketones, polyketides, alkaloids, non-alkaloids, acids, coumarins, etc., which comprise numerous potent biological activities including antimicrobial, anticancer, antioxidant, insecticidal, antidiabetic, immunosuppressive, anti-arthritis, anti-inflammatory, and anti hypercholesterolemic. Around 1.5 million endophytic fungal species have been estimated. However, to date, only 100,000 species are reported. Thus, a few isolated compounds and their biological activities have been opted in this current review. All compounds were discovered from endophytic fungi, which resided on various host plants, particularly from algae to a higher family plant such as mangroves.
\end{abstract}

Keywords: endophytic fungi, medicinal plants, secondary metabolite, biological activity

\section{INTRODUCTION}

Up to $80 \%$ of the people in Asia, Latin America, and Africa use their local plants to treat numerous diseases (Maghrani et al., 2005). In general, the survival of the plants relates to their physical and chemical defense system. During the unfavorable changes, the plants are forced to synthesize unique substances, which researchers enunciated as secondary metabolites, bioactive compounds, or natural products. The production of these compounds can be mimicked by the microbial inhabitant of the host plant, which is known as endophytes. They are a valuable source of new chemicals with possible usages in the medicinal, agricultural, and industrial sectors (Hyde \& Soytong, 2008). It has been reported by Sharma et al. (2020) that $46 \%$ of pharmacological activity from endophytes is the antimicrobial agent. It is followed by anticancer (40\%), antioxidant (16\%), anti-inflammatory $(12 \%)$ and toxicity against brine shrimp (8\%). The research on novel therapeutic compounds using endophytes was triggered by Martinus Willem Beijerinck during his important finding on root nodule bacteria, which can fix atmospheric nitrogen (Hardoim et al., 2008). Since then, a number of reports on biological activities of secondary metabolites

*Author for correspondence: Woei Yenn Tong, Universiti Kuala Lumpur, Branch Campus Malaysian Institute of Chemical and Bioengineering, Lot 1988, Kawasan Perindustrian Bandar Vendor, Taboh Naning, 78000 Alor Gajah, Melaka, Malaysia. Email - wytong@unikl.edu.my 
originated from endophytes were vastly recognized.

Endophytic fungal research has received much attention recently. Endophytic fungi are capable to colonize the terrestrial plants worldwide. They are discovered in plants growing in the humid and seasonal wet tropics, temperate environments, and boreal forests, ranging from extreme arctic to tropical forests. The fungi have been isolated from several angiosperms, gymnosperms, bryophytes and tracheophytes (Rodriguez et al., 2009). Hawksworth (1991) estimated that about 100,000 species out of 1.5 million endophytic fungi had been reported. Endophyte-free plants are very rarely reported. The discovery of endophytes was relatively early, but little recognition has been done. Most of the reports put a special highlight on plantendophytes interaction. In many cases, antimicrobial actives produced by endophytic fungi have been related to dominate a broad spectrum of chemical classes, such as ketones, polyketides, alkaloids, non-alkaloids, acids, coumarins, and etc. In general, these actives have been related to several mechanisms of action in order to perform their antimicrobial activity against pathogens. For instance, the actives own the ability to affect cell division, inhibit the enzyme production by microbes, disrupt the microbial membrane and alter virulence genes (Khameneh et al., 2019; Othman et al., 2019). These advantages are promising to human health, especially in deciphering the issue of antibiotic resistance by pathogens.

\section{Relationship of endophytic fungi and novel bioactive compounds}

According to $\mathrm{Yu}$ et al. (2010), most of the fungi are isolated from medicinal plants (35\%), followed by crops $(29 \%)$, plants in special environments $(18 \%)$ and other plants (18\%) (Figure 1). It is noteworthy to mention that numerous endophytes are capable to mock similar compounds with their host plants. The relationship of endophytic fungi and their host plant is based on a unique adaptation. Through this condition, fungi could synchronize their growth with the host plant (Verma et al., 2012). Other than commensal association or neutralism, endophytes can survive on their host via parasitic and mutualistic relationships (Gouda et al., 2016).
The relationship depends on the genotype of the endophyte and the host plant itself. Besides that, the environmental condition is also an important key in selecting the relationship (Faeth \& Fagan, 2002). However, most endophytic fungi are mutualists since they gain nutrition and protection from the host plant. As a return, they offer an extra competitive ability and resistance against plant-eating animals, insects, pathogens, and abiotic stresses (Oukala et al., 2021). To protect the synergistic relationship with the host plant, the endophytic fungi confer three beneficial offers; (1) producing growth hormones to the host (Waqas et al., 2012), (2) increasing the host resistance to biotic and abiotic stresses by generating specific bioactive compounds (Rodriguez et al., 2009), and (3) endorsing the accretion of secondary metabolites such as medicinal drugs (Shwab \& Keller, 2008). Most of the endophytic fungi are antimicrobial agents. In Asian medicinal plants, they represent $46 \%$ of the total findings (Figure 2). The endophytic fungi are also actively reported to be an agent for anticancer, anti-inflammatory, antioxidant, antidiabetic, and other biological activities. According to this persuasive potential, it is well worth exploring and investigating the novel endophytic fungi, which might offer a better option in treating human diseases.

\section{Endophytic fungi as an antimicrobial agent}

Several novel antibiotics that are medically potent can be isolated from endophytic fungi (Strobel \& Daisy, 2003). Many new antimicrobial compounds were isolated from Phomopsis and its anamorph Diaporthe. Four pyrenosines, known as phomopsinone A, B, C, and D were discovered from Phomopsis sp., which resided in the stems of Santolina chamaecyparissus (Hussain et al., 2012a). It has been reported that Botrytis cinerea, Pyricularia oryzae, and Septoria tritici were vulnerable to phomopsinone A. The antimicrobial activity of phomopsinone A was represented by the highest inhibition zones ranged from 17-25 $\mathrm{mm}$. Meanwhile, phomopsinone B manifested moderate antifungal and antibacterial activities, particularly against $P$. oryzae, Microbotyrum violaceum, S. triciti, Escherichia coli and Bacillus megaterium. Phomopsinone C also showed moderate inhibitory activities against $M$. violaceum, E. coli, and B. megaterium, while phomopsinone D 
moderately inhibited fungi Botryis cinerea and $S$. tritici. The inhibition zones caused by these drugs were specifically $\leq 10 \mathrm{~mm}$. Another 4 pyrenosines, namely pyrenosines $\mathrm{J}, \mathrm{K}, \mathrm{L}$ and $\mathrm{M}$ were isolated from Phomopsis sp. residing in Cistus salvifolius (internal strain 7852) by the same group of the researcher. All the compounds exhibited antibacterial properties on $E$. coli and, $B$. megaterium, however only pyrenosines J, K, and, $\mathrm{M}$ showed antifungal properties against $S$. tritici and, M. violaceum (Hussain et al., 2012b). Later Sun et al. (2013a) have discovered four types of hydroxyanthraquinones, together with four new analogs (coniothyrinones A-D) containing tetralone moiety from endophytic fungus Coniothyrium sp. This fungus was found on Salsola oppostifolia plant. All compounds showed antibacterial activity against $B$. megaterium. The radius of inhibition zone was ranged from 7-16 $\mathrm{mm}$. The compounds have also signified moderate biological activity on E. coli, except hydroxyanthraquinones 1 . Interestingly, Tong et al. (2017) have discovered a novel ketone derivative, 3-hydroxy-5-methoxyhex-5-ene-2,4dione, from Diaporthe sp. ED2, which was isolated from medicinal plant Orthosiphon stamineus. The heat-stable compound exhibited significant fungicidal activity on Candida albicans at MIC and minimal fungicidal concentration (MFC) of 3.1 $\mu \mathrm{g} / \mathrm{mL}$ and $12.5 \mu \mathrm{g} / \mathrm{mL}$, respectively. The test compound has reduced $99.9 \%$ of viable cell count after 36 h of exposure to C. albicans.

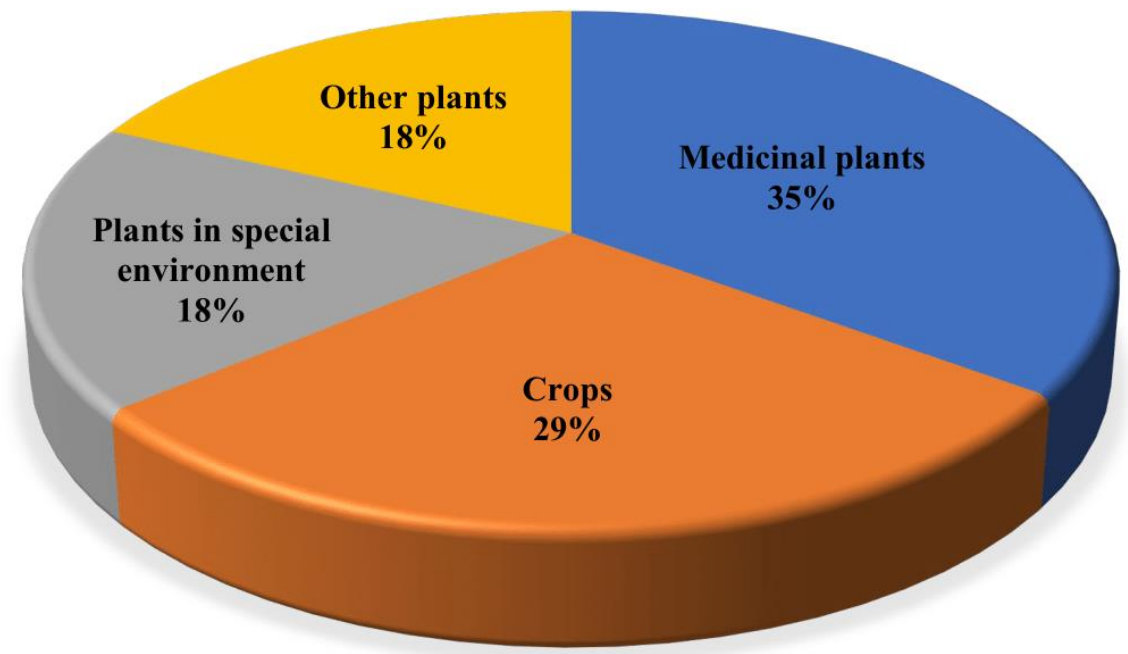

Figure 1. Percentage of endophytic fungi from different host sources (adapted from Yu et al., 2010.

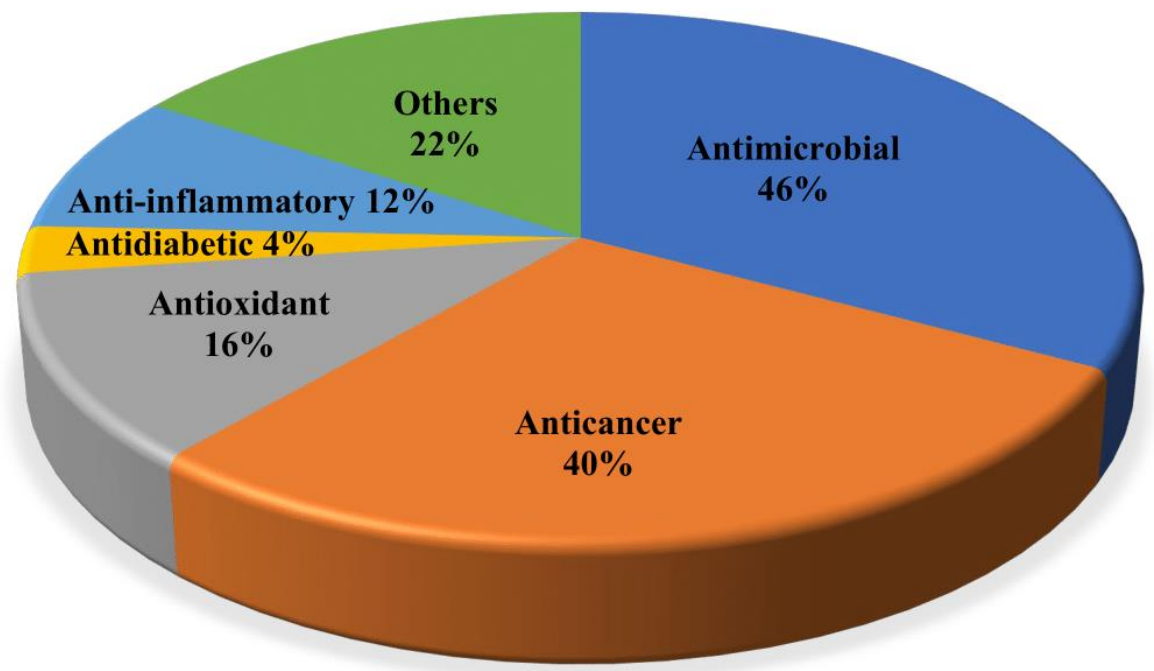

Figure 2. Biological activities of various endophytes isolated from medicinal plants in Asia (adapted from Sharma et al., 2020). 
Marine and mangrove ecosystems are commonly known as great reservoirs for novel antimicrobial compounds. Sebastianes et al. (2012) has reported the production of 3hydroxypropionic acid (3-HPA) from an endophytic fungus, Phomopsis phaseolorum. This fungus was isolated from mangrove's branches of Laguncularia racemose. 3-HPA showed the antibacterial effect on Staphylococcus aureus and Salmonella typhi, with minimal inhibitory concentration (MIC) of $64 \mu \mathrm{g} / \mathrm{mL}$. However, the value was less compelling than tetracycline. Pestalotiopen A was firstly isolated from Pestalotiopsis sp., which resided on a Chinese mangrove Rhirophora mucronate. It is suggested that cyclopaldic acid and altiloxin B become cooccurring precursors during the biosynthesis of pestalotiopen A. The compound revealed moderate antibacterial efficiency on Enterococcus faecalis, with MIC values ranged from 125-250 $\mathrm{mg} / \mathrm{mL}$ (Hemberger et al., 2013). Cristatumin A and tardioxopiperazine $\mathrm{A}$ is an indole alkaloid extracted from Eurotium cristatum sp. EN-220 from Sargassum thunbergii. The compound inhibited both E. coli and $S$. aureus at MIC values of $64 \mu \mathrm{g} / \mathrm{mL}$ and $8 \mu \mathrm{g} / \mathrm{mL}$, respectively (Du et al., 2012). Other metabolites, which are named as isorhodoptilometrin-1-methyl ether and siderin, have shown antibacterial activity against indicator strains of B. cereus, B. subtilis and S. aureus. Against these bacteria, siderin slightly emerged a better antibacterial activity than isorhodoptilometrin-1methyl ether, with a radius of inhibition zone ranged from 12-15 $\mathrm{mm}$. Both compounds were isolated from Aspergillus versicolor, which was initially from red sea algae (Hawas et al., 2012). Two novel antimicrobial compounds of xanthone derivatives, namely yicathin $\mathrm{B}$ and $\mathrm{C}$ were discovered from endophyte Aspergillus wentii PT- 1 of Gymnogongrus flabelliformis, the red marine alga originated from Pingstan Island, China. Yicathin $B$ could potentially inhibit E. coli, with $9 \mathrm{~mm}$ inhibition zone. Meanwhile, yicathin $\mathrm{C}$ has a broader spectrum of the antimicrobial activity than yicathin B. It was active against bacteria and fungus that of E. coli, S. aureus and Colletotrichum lagenarium, with $12 \mathrm{~mm}, 7.5 \mathrm{~mm}$ and $11 \mathrm{~mm}$ inhibition zones, respectively (Sun et al., 2013b). The sub-toxicity values for both compounds were $0.22 \mathrm{mmol} / \mathrm{L}$ (Yicathin B) and $0.30 \mathrm{mmol} / \mathrm{mL}$ (Yicathin C). It is also noteworthy to report a newly discovered antibacterial compound that originated from marine-derived Aspergillus flavipes. The compound is aromatic butyrolactone, which is known as Flavipesins A. It functioned as a potent antibacterial agent against $S$. aureus (MIC $=$ $8 \mu \mathrm{g} / \mathrm{mL}$ ) and B. subtilis (MIC $=0.25 \mu \mathrm{g} / \mathrm{mL}$ ). This compound penetrated via the biofilm matrix of the matured $S$. aureus and killed the available free-living cells in the biofilm (Bai et al., 2015). A novel ketone derivative (3,1'-didehydro3[2"(3"',3'"-dimethyl-prop-2-enyl)-3"-

indolylmethylene]-6-methyl pipera-zine-2,5dione) was isolated from Penicillium chrysogenum MTCC 5108. This fungus mutually resided on the leaves of the mangrove plant Porteresia coarctata (Roxb.). The antibacterial activity of the identified compound was relative to commercial streptomycin. Both drugs displayed a comparable range of inhibition zone, that of $14-16 \mathrm{~mm}$, against Vibrio cholerae (Devi et al., 2012). Huang et al. (2017) reported a new antraquinone derivative from mangrove endophyte Phoma sp., isolated from Myoporum bontiodes A roots, which is called 7methoxymacrosporin. By comparing with the positive control carbendazim, 7methoxymacrosporin owned a potent antifungal activity on Fusarium oxysporum with MIC value equal to $3.75 \mu \mathrm{g} / \mathrm{mL}$.

Pyrrocidine $\mathrm{C}$ was first recovered from Lenvia infectoria SNB-GTC2402, an endophytic fungus found in the tropical leaf, Besleria insolita. The compound has an antibacterial efficiency against Gram-positive S. aureus ATCC 29213, with MIC equivalent to $2 \mu \mathrm{g} / \mathrm{mL}$ (Casella et al., 2013). Cheng et al. (2012) have reported that higher MIC values, that of $5.12 \mathrm{mg} / \mathrm{mL}$ and $2.52 \mathrm{mg} / \mathrm{mL}$, were needed by biscogniazaphilones $\mathrm{A}$ and $\mathrm{B}$ to inhibit Mycobacterium tuberculosis. These two novel antimycobacterial azaphilone derivatives were discovered from Biscogniauxia formosana BCRC 33718, which was originally from the bark of a Cinnamomum sp. A new phenolic chemical, 4(2,4,7-trioxa-bicyclo [4.1.0]heptan-3-yl)-phenol was previously isolated from Pestalotiopsis mangifera, a fungus isolated from the mango tree. The compound manifested significant inhibitory activity on both Gram-positive and Gramnegative bacteria as well as yeast. The MIC values were ranged from 0.039 to $5.0 \mu \mathrm{g} / \mathrm{mL}$, with the lowest value recorded by B. subtilis, $K$. pneumoniae and $C$. albicans. According to the microscopic 
evaluation, this compound destroyed bacterial cells through cytoplasm cohesion (Subban et al., 2013).

Budhiraja et al. (2013) discovered another new chemical, KL-4 or 6-methyl-1,2,3-trihydroxy-7,8cyclohepta-9,12-diene-11-one-5,6,7,8-tetralene-7acetamide. It was from Aspergillus sp., which was previously isolated from the seeds of medicinal plant Gloriosa superba Linn. The identified compound displayed an excellent antimicrobial activity on S. aureus, E. coli, Saccharomyces cerevisiae, C. albicans, $P$. aeruginosa, B. subtilis, and Cryptococcus gastricus. The susceptibility of these microbes on the test compound was signified by the inhibition zone, with an average diameter from 11.9 to 18.9 $\mathrm{mm}$. Moreover, several novel polyketides were also discovered from endophytic fungi including 7,8-dihydonivefuranone A, 6(7)-dehydro-8hydroxyterrefuranone, 6-hydroxyterrefuranone and nivefuranones A. These compounds were isolated from Microdiplodia sp. KS 75-1, an endophytic fungus inhabiting in the stems of Pinus sp. Against $C$. albicans and $S$. aureus, the newly purified compounds manifested a compelling range of inhibition zones on both microbes vi\%: 15-16 $\mathrm{mm}$ (S. aureus) and 13-15 $\mathrm{mm}$ (C. albicans) (Shiono et al., 2012). Saleem et al. (2013) have reported the antibacterial efficacy of cryptosporioptide. This polyketide can inhibit the growth of $B$. megaterium. It was extracted and isolated from Cryptosporiopsis sp., which was originally from the shoot tissue of Viburnum tinus. Based on agar diffusion test, this compound has moderately inhibited $B$. megaterium with a $9 \mathrm{~mm}$ diameter of inhibition zone. This zone was smaller than positive control penicillin $(26 \mathrm{~mm})$ and streptomycin (13 mm). Senadeera et al. (2012) have reported a potentially antibacterial polyketide compound, that of dothideomycetide A, against S. aureus ATCC 25923 and methicillin resistant $S$. aureus ATCC 33591. It was isolated from Dotbideomycete sp., which was originally from the Thai medicinal plant Tiliacora triandra. This compound presented antibacterial activity on $S$. aureus and MRSA with corresponding MIC values of 128 and $256 \mu \mathrm{g} / \mathrm{mL}$.

\section{Endophytic fungal products as anticancer agents}

Cancer has become one of the most leading causes of death worldwide, which approximately
10 million people died from this disease in 2020 . The number of cases is estimated to increase by $47 \%$ in 2040, accounting for 28.4 million cases (Sung et al., 2021). Among cancer diseases, lung cancer is the major killer in humans. It has represented $18.4 \%$ of total cases. Besides, lung cancer is recognized as the most diagnosed disease alongside breast cancer $(11.6 \%)$. It is closely tailed by prostate cancer $(7.1 \%)$, colorectal cancer $(6.1 \%)$, stomach cancer $(8.2 \%)$, and liver cancer $(8.2 \%)$ (Bray et al., 2018). There are several actives from endophytic fungi, which scientists believed can be an optional drug against cancerous cells. The potential actives are discussed in this section.

\section{Paclitaxe1}

Paclitaxel, or commercially known as taxol was discovered in 1960 from a screening program of antitumor activity held by National Cancer Institute (Weaver, 2014). It is the world's first billion-dollar project using fungi as an anticancer agent, though the drug is primarily isolated from the bark of Taxus brevifolia. Large-scale production of the compound has caused a delay on the clinical development of taxol (El-Sayed et al., 2020). Researchers have acknowledged Taxus sp. (yew) as a key of interest due to their potential in producing taxol. It has been stated that taxol produced by Taxus sp. could be the chemical that protects the yew tree since this plant is lethal to numerous pathogenic oomycetes including Phytophthora sp., Pythium sp. and Aphanomyces sp. The mystery is solved with the finding of fungus Taxomyces adreanea in $T$. brevifolia as a paclitaxel producer. A detection via electrospray mass spectrum using culture fluid of this fungus has confirmed the presence of paclitaxel. There were two peaks observed i.e. $(\mathrm{M}+\mathrm{H}+)$ and $(\mathrm{M}+\mathrm{Na}+)$ at $m / z .854$ and $m / z .876$, respectively. The peaks are identical with authentic taxol (molecular formula: $\mathrm{C}_{47} \mathrm{H}_{51} \mathrm{NO}_{14}$ ) (Strobel et al., 1997). Moreover, the investigations relate to the $14 \mathrm{C}$ label unquestionably demonstrated the existence of taxol-derived fungus in the culture medium. In 1996, Strobel and co-researchers have isolated paclitaxel from an endophytic fungus, Pestalotiopsis microspore, which originally from inner bark of Himalayan yew, Taxus wallichiana. They found out that [I4C]acetate and [14C]phenylalanine are served as precursors for [I4C]taxol in fungal 
culture labeling analyses. Xiao et al. (2012) have confirmed that this 14C-label could increase uptake by tumor tissue and slow down pharmacokinetics on cancerous mice models. It is worth to mention a more recent discovery of taxol producing endophytic fungi such as Tubercularia sp. It was isolated from Chinese yew or Taxus mairei (Wang et al., 2000). Based on the immunofluorescence result, this fungal taxol has altered the intracellular microtubule arrays, which relative to commercial taxol. This event has allowed mitotic arrest and cytotoxicity on cancerous cells. Other than 14C-label, taxol can also be detected according to the BAPT gene (C13 phenylpropanoid side chain-CoA acetyltransferase). Garyali et al. (2013) have discovered this method during the taxol identification produced by Fusarium redolens. The BAPT gene is reported to associate with the taxol biosynthetic pathways. However, the production was low as only $66 \mu \mathrm{g} / \mathrm{L}$ of taxol generated in fermentation broth.

In 2011, Colletotrichum capsici was isolated from the infected fruits of chili plant Capsicum annuum, which was later identified as taxol-producing fungus. The highest amount of fungal taxol production was $687 \mathrm{mg} / \mathrm{L}$, with a production rate of 13740-fold (Kumaran et al., 2011). Another taxol producer was Seimatoantlerium tepuiense. It was isolated from Maguireothamnus speciousus, a widespread plant which commonly can be found on the table-top mountain of the VenezuelanGuyana region in southwestern Venezuela (Zhang $\&$ Demain, 2005). These reports have proven that the distribution of taxol producing endophytic fungi in plants are varied and not only limited to yews. The worldwide distribution of the fungi is related to the fungicidal characteristic of taxol. As recorded, Pythium sp. and Phytophthora sp. are the most sensitive plant pathogens on taxol (Young et al., 1992).

The existence of a trace number of unattached kinetochores in taxol has become a hallmark cytotoxic property against human cervical cancer cells (HeLa). At nanomolar concentrations, this compound can arrest cells which is available at the mitotic (M) phase of the cell, without interruption of the synthesis (S) phase (Waters et al., 1998). Besides, this compound owns the ability to improve the polymerization of stable microtubules (Wani and Horwitz, 2014). The result was in line with the previous findings as taxol could stabilize the microtubules by promoting the polymerization process and at the same time obstructing the depolymerization. According to this exceptional mode of action, taxol is acknowledged as the latest class of antineoplastic agents (Schiff et al., 1979; Horwitz et al., 1986). By inducing the activation of the mitotic checkpoint, taxol provides a pause in the division of chromosomes entering mitosis as copied pairs of sister chromatids. This process continued until each pair has formed secure adhesions to both mitotic spindle poles. Therefore, each cell will obtain one replicate of every chromatid. The chromatids link to spindle microtubules via kinetochores, which are a cluster of protein structures that build on centromere parts of DNA. Free kinetochores which formed fragile attachments to microtubules have alternately initiated a signal transduction cascade to slow down mitotic progression. This process has been done by averting the anaphase endorsing complex or cyclosome (Foley \& Kapoor, 2013).

\section{Camptothecin}

In 1966, Wall and Wani isolated a potential antitumor agent from Camptotheca acuminata, which is known as camptothecin (CPT). It is a type of pentacyclic pyrroloquinoline alkaloid that stabilizes the reversible covalent DNAtopoisomerase I complex. Topoisomerase I relax DNA by breaking it, prior to resealing step of a single strand of DNA. Consequently, it discharges the torsional strain that ensues through DNA transcription and replication (Chu et al., 2014). It has been reported that CPT derivatives comprised the anticancer activity of both in vitro and in vivo. The parental compound of 10hydroxycamptothecin, topotecan (TPT), irinotecan (CPT-I 1), and SN-38 is alkaloid CPT (Thomas et al., 2004). Previous reports claimed that CPT is naturally produced by several other plant species including Camptotheca acuminata Decaisne (Nyssaceae) and Nothapodytes foetida (Padmanabha et al., 2006; Pu et al., 2013). The high request for $\mathrm{CPT}$ has been rooted in the mass harvesting of these two plants in recent years. As an alternate strategy, researchers have put a weight on the habitant of the plants or endophytic microorganisms in finding a new CPT source. 
In the recent past, the first report of CPTproducing endophytic fungus, specifically Entrophospora infrequens, was discovered by Puri et al. (2005). This fungus was isolated from the inner bark of Nothapodytes foetida. The fungus was grown in a shake flask and bench-scale system containing a synthetic submerged medium (Sabouraud broth). The fermentation process has allowed the fungus to synthesize the similar anticancer compound or CPT generated by the host tree itself. This finding encourages a more wideranging search of other plants. The interest in investigating other endophytic sources of CPT and its derivatives from different plant sources has certainly been revived by these interesting findings. Rehman et al. (2008) reported a potential source of CPT from endophytes of $N$. foetida seed. It has been recorded by Min and Wang (2009) that there was an anonymous endophytic fungal strain XK001 from C. acuminata could generate $10-\mathrm{OH}-$ CPT. Furthermore, CPT and its analogs specifically 9-methoxy camptothecine (9-MeOCPT) and 10-OH-CPT were successfully isolated from endophytic fungi. The fungi were originally from C. acuminata and Apodytes dimidiata (Icacinaceae) (Kusari et al., 2009; Shweta et al., 2010). Based on Chu et al. (2014), CPTs signified an essential class of anticancer drugs. Their capabilities in inhibiting several solid tumors such as lymphoma, gastric cancer as well as colorectal cancer have been widely reported by researchers.

\section{Vinblastine and vincristine}

Vinblastine and vincristine, which are isolated from the leaves of Catharanthus roseus, are excellent anti-cancer medicines. It is a short-lived perennial that belongs to the family of Apocynaceae and contains more than one hundred medicinal terpenoid indole alkaloids, including the two main vinca alkaloids, vincristine and vinblastine (Palem et al., 2015). The mechanisms of action of vincristine are represented with the intrusion of microtubule development and mitotic spindle dynamics. In addition, it causes a disturbance of intracellular transport and also able to reduce tumor blood flow. Vincristine is isolated from Fusarium oxysporum, an endophyte of $C$. roseus (Zhang et al., 2000; Tung et al., 2002). This compound has been produced by Alternaria sp., which is isolated from the same plant found in China (Guo \& Kunming, 1998). Kumar et al.
(2013) have reported on the isolation of fungus AA-CRL-6 from C. roseus, which could generate vinblastine and vincristine. This fungus was distinguished according to its cultural and morphological characteristics as well as molecular approach via internal transcribed spacer (ITS) sequence evaluation. It was identified as $F$. oxysporum. Palem et al. (2015) have reported their work on vincristine and vinblastine-producing fungus, Talaromyces radicus which also been isolated from C. roseus.

\section{Podophyllotoxin}

Podophyllotoxin (PDT) is a well-known natural aryl tetralin lignan produced by a few plant species. Commonly, it is implemented to be a precursor in some chemical synthesis which involved anticancer drugs such as etoposide, teniposide and etopophosphate phosphate (Nadeem et al., 2012). To date, sinopodophyllum is the main plant reservoir for podophyllotoxin. Sinopodophyllum plants have been declared imperiled as over-exploitation species due to the mass harvest. An alternative resource and strategy for producing this important compound effectively should be developed in order to meet the growing demand. Yang and co-researchers have identified about six endophytic fungi that could produce PDT particularly from Sinopodophyllum hexandrum, Diphylleia sinensis and Dysosma veitchii (Yang et al., 2003). Subsequently, Lu et al. (2006) have also stated that PDT could be generated from an endophytic Alternaria sp., which was previously obtained from Sabina vulgaris. Two endophytic strains of Phialocephala fortinii, specifically PPE5 and PPE7, could produce PDT in submerged suspension culture. The fungi were isolated from Sinopodophyllum peltatum and generated about 0.5 to $189 \mu \mathrm{g} / \mathrm{L}$ in yield (Eyberger et al., 2006). Puri and Coresearchers have also reported PDT and its glycoside in broth culture which was initially isolated from an endophytic fungus Trametes birsute. This fungus was purified from Sinopodophyllum hexandrum (Puri et al., 2006). Cao et al. (2007) have confirmed that an endophytic fungus, specifically Alternaria sp., which isolated from $S$. hexandrum could generate PDT. Kour and co-researchers have also recognized a PDTgenerating endophytic fungus $F$. oxysporum attained from Sabina recurva in 2008 (Kour et al., 
2008). The latest report by Nadeem et al. (2012) showed the synthesis of PDT by an endophytic fungus Fusarium solani isolated from the roots of Podophyllum hexandrum. HPLC and mass spectrometry have confirmed and quantified the existence of PDT in fungal biomass. These findings provide us with a promising way to explore endophytic fungi as an optional source for PDT and its analogs.

\section{Other anticancer agents}

A later report by Tawfike et al. (2019) have revealed seven actives isolated from $A$. flocculus. However, only five actives, specifically cis-4hydroxymellein, 5-hydroxymellein, diorcinol, botryoisocoumarin $\mathrm{A}$ and mellein ${ }_{2}$ exhibited an anticancer effect on the formation of a chronic myelogenous leukemia cell line. Majoumouo et al. (2020) have disclosed the cytotoxicity prospective of Trichoderma sp. extract against human cervical cancer cells. This endophytic fungus was previously isolated from Terminalia catappa. The N97 extract owned a notable anticancer effect on human cervical cancer cells with a 50\% inhibitory concentration (IC50) equal to $33.35 \mu \mathrm{g} / \mathrm{mL}$. A higher IC50 value was exhibited by other tested extracts including N223 $(136.8 \mu \mathrm{g} / \mathrm{mL}), \mathrm{N} 169$ $(149.2 \mu \mathrm{g} / \mathrm{mL})$ and $\mathrm{N} 2(175.8 \mu \mathrm{g} / \mathrm{mL})$. In addition, it was verified that the growth inhibitory potential of the Trichoderma sp. extract on cancer cells was intervened via apoptosis during the application of N97 extract. Chemical structures of important anticancer agents are displayed in Figure 3.

\section{Endophytic fungal products as antioxidant agents}

The antioxidant is referred to any constituent that interrupts, stops, or eradicates oxidative defect to a target molecule. Endophytes are a perfect source of compounds with antioxidants. Two compounds, specifically terreic acid and 6methylsalicylic acid, were obtained from Pseudocercospora sp. ESL 02, an endophytic fungus isolated from a plant called Elaeocarpus sylvestris.
Both compounds have displayed a promising result on DPPH radical scavenging activity, mitigating power assay and $\beta$-carotene bleaching assay (Prihantin $\&$ Tachibana, 2017). In a previous report, terreic acid is a bioactive compound, which commonly derived from 6-methylsalicylic acid (6-MSA) (Guo et al., 2014). The ability of terreic acid to scavenge toward free radicals is based on its quinine group which serves a major role in bringing a balance between antioxidants and reactive oxygen species generated within the system. Moreover, the potential of this compound as an antioxidant agent was supported by Dewi et al. (2012). They have validated that terreic acid isolated from ethyl acetate extract of Aspergillus terreus LS01 displayed a moderate radical scavenging activity. Furthermore, Aspergillus genera are extensively described to produce numerous secondary metabolites such as wentiquinone $\mathrm{C}$, methyl 4-(3,4dihydroxybenzamido)butanoate (Li et al., 2014) and exopolysaccharide As1-1 (Chen et al., 2011). After several years of effort, it has been reported that two compounds, specifically pestacin and isopestacin, are produced by $P$. microspore. This endophytic fungus was discovered by Harper et al. (2003) from Terminalia morobensis plant. Both pestacin and isopestacin possess a potent antioxidant activity which relative to the flavonoids. Graphislactone A, a metabolite purified from an endophytic Cephalosporium sp., displayed an antioxidant activity as well as free radical scavenging. The in vitro assessment of the compound showed stronger antioxidant activity than butylated hydroxytoluene (BHT) and ascorbic acid. During radical scavenging activity test, Graphislactone A has manifested a lower IC50 value than BHT viq. $9.6 \mu \mathrm{M}$ and $19.5 \mu \mathrm{M}$, respectively. As for ascorbic acid, a dire elevation in linoleic acid peroxidation was observed after 30 $\mathrm{h}$, with $\mathrm{OD}_{500 \mathrm{~nm}}$ more than 0.6. The condition was equivalent to that of the blank. On the other hand, Graphislactone A has recorded a 4.4-fold decrease of linoleic acid peroxidation at a similar experimental period (Song et al., 2005). 


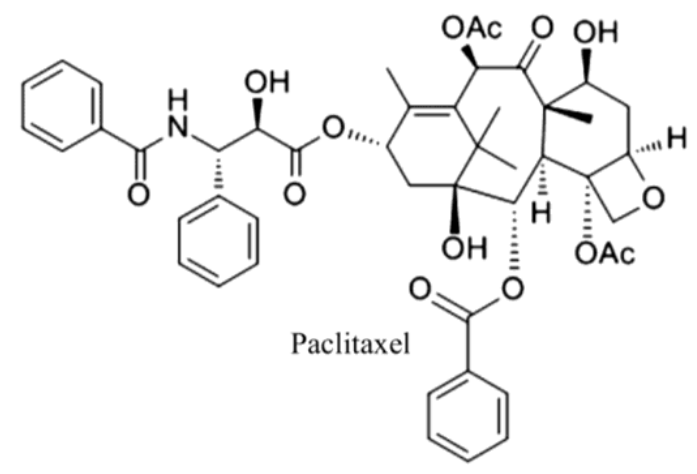<smiles>CNc1ccccc1</smiles>

cis-4-hydroxymellein<smiles>C[C@@H]1OC(=O)c2c(O)cccc2[C@H]1O</smiles>$$
\text { cis-4hy roxymellein }
$$<smiles>CC1Cc2c(O)ccc(O)c2C(=O)O1</smiles>

Vinblastine<smiles>CC[C@]1(O)C(=O)OCc2c1cc1n(c2=O)Cc2cc3ccccc3nc2-1</smiles>

Camptothecin

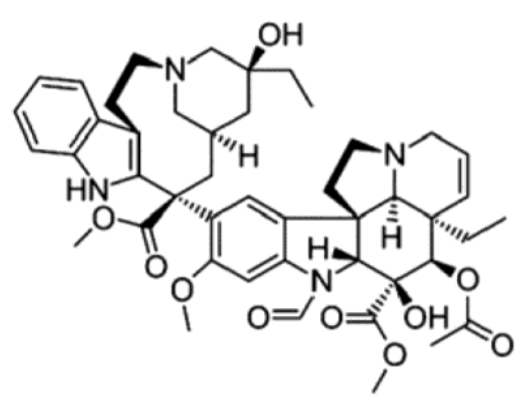<smiles>COc1cc([C@H]2c3cc4c(cc3[C@@H](O)[C@@H]3COC(=O)[C@H]23)OCO4)cc(OC)c1OC</smiles>

Podophyllotoxin<smiles>Cc1cc(O)cc(Oc2cc(C)cc(O)c2)c1</smiles>

Diorcinol<smiles>CC1Cc2cccc(O)c2C(=O)O1</smiles>

Figure 3. Structures of bioactive compounds with anticancer efficiency isolated from different endophytic fungi (adapted from Strobel et al., 2003; Eyberger et al., 2006; Shweta et al., 2010; Kumar et al., 2013; Tawfike et al., 2019).

\section{Antidiabetic agent}

Medically, diabetes insinuates a cluster of metabolic diseases described by conditions with high blood glucose concentration (hyperglycemia) linked to insufficient insulin production or the body's cells failed to respond properly to insulin, or both (Ushasri \& Anusha, 2015). It is one of the most common diseases that causes serious public health concerns as there are limited drugs available for treatment. Thus, many investigations are focused on novel antidiabetic drugs from endophytic fungi (Dhankhar et al., 2013; Prabavathy \& Vallinachiyar, 2013; Singh \& Kaur, 2016). A purified peptide molecule from Aspergillus awamori isolated from Acacia nilotica has showed antidiabetic activity. The compound obtained from the study has dual inhibitory activity, particularly $\alpha$-glucosidase $(80 \%)$ and $\alpha$ amylase $(81 \%)$. Furthermore, it has low IC50 values $(\alpha$-glucosidase $=5.625 \mu \mathrm{g} / \mathrm{mL} ; \alpha$-amylase $=3.75 \mu \mathrm{g} / \mathrm{mL})$ and stable at high temperature and $\mathrm{pH}$. The peptide retained $80 \%$ of inhibitory 
activity after $1 \mathrm{~h}$ exposure to a temperature of $80^{\circ} \mathrm{C}$. By virtue of these characteristics, this compound can be commercially produced (Singh \& Kaur, 2016). Zhang et al. (1999) have reported a different antidiabetic compound. It is a nonpeptide fungal metabolite vi\%: demethylasterriquinone $\mathrm{B} 1$, which was isolated from the endophytic fungus, Psendomassaria sp. Originally, it was collected from an African rainforest in Congo. This compound showed a significant result of lowering blood glucose levels in the mouse model. The similar outcome was reported during the application of $\mathrm{N}$ acetylgalactosamine (lectin) on alloxan-induced diabetic rats. This antidiabetic agent was isolated from Alternaria species, an endophyte of the plant Viscum album. It has inhibited three diabetic components, particularly $\alpha$-amylase, $\alpha$-glucosidase and sucrase. Interestingly, the compound displayed an increase in mice body weight by $8.5 \%$ after 14 days of experimental period (Govindappa et al., 2015).

\section{Immunosuppressive agent}

Immunosuppression is the process that acts to decrease the activation or efficacy of the immune system by cell-mediated immunity. Immunosuppressive agents are molecules that inhibit or prevent the activity of the immune system involved in autoimmune diseases or organ transplants. A sample of plant materials of Pteromischum sp. collected from a rainforest in Costa Rica was found an endophytic fungus, Colletotrichum dematium which strongly inhibited Botrytis cinerea, a typical plant pathogen on the leaves and flowers. The fungus C. dematium produced a molecule, Colutellin A, which chemically and biologically resemblances to cyclosporin A, an important immunosuppressive drug (Rüegger et al., 1976).

Immunosuppressive drugs, such as Subglutinol A and Subglutinol B, were used to avert transplant rejection in patients. The drugs were produced by Fusarium subglutinans, an endophytic fungus from the perennial twiningtype vine Tripterygium wilfordii. Both Subglutinol A and Subglutinol B were discovered to be equipotent with IC50 of $0.1 \mu \mathrm{M}$ in the thymocyte proliferation assay and lymphocyte reaction assay (Lee et al., 1995). Chloroform and methanolic extracts of endophytic fungus Entrophospora infrequens isolated from $N$. foetida have exhibited immunomodulatory potential in mice models. At a concentration range of $12.5-100 \mathrm{mg} / \mathrm{kg}$ body weight, the chloroform extract has accelerated the humoral and cell-mediated immune responses in a dose-dependent pattern. As for the methanolic extract, it induced the delayed-type hypersensitivity (DTH), plaque-forming cell assay, phagocytic response, haemagglutination antibody titer and immunoglobulin $\mathrm{G}$ by $80 \%$, $33 \%, 38 \%, 79.07 \%$ and $62.05 \%$, respectively. These occasions happened at a concentration of $12.5 \mathrm{mg} / \mathrm{kg}$ body weight (Puri et al., 2007). It is also notable to expose a compound, which was known as BS compound. The compound was isolated from the fungus, Pestalotiopsis leucothes, an endophytic fungus of the plant Tripterygium wilfordii. It showed immunomodulatory activity with IC50 value $\leq 0.35$ during the proliferative assays. Additionally, this compound has a variable impact on T cells, B cells and monocytes (Kumar et al., 2005).

\section{Anti-arthritis and anti-inflammatory activities}

Arthritis is the inflammation of tissues in the joints with chronic systemic autoimmune disease, characterized by pain, swelling, and obliteration of cartilage and bone which leading to permanent disabilities. Currently, researchers are drawing a great interest to expedite the search of biomolecules from endophytic fungi associated with medicinal plants due to certain side effects of the available drugs (Choudhary et al., 2015). An endophytic fungal screening program is crucial in finding an inhibitor for pro-inflammatory cytokines. Molecules from endophytic fungal Talaromyces wortmannii, which was isolated from Aloe vera, showed potent anti-inflammatory activity. The result exhibited that retardation of IL-8 release was executed by obstructing the NF$x \mathrm{~B}$ and AP-1 activation (Pretsch et al., 2014). Simultaneously, mutolide isolated from the fungus Lepidosphaeria sp. has also disclosed an exceptional anti-inflammatory activity. At 100 $\mathrm{mg} / \mathrm{kg}$ body weight, mutolide manifested notable inhibition of lipopolysaccharide (LPS)-induced release of tumor necrosis factor-alpha and interleukin 6 from acute inflammation mice models. It blocked both pro-inflammatory cytokines, with an IC50 equivalent to $1.27 \pm 0.06$ and $1.07 \pm 0.02 \mu \mathrm{M}$, correspondingly. As 
observed, the process did not affect the viability of the cells. This compound is a better candidate for treating inflammatory diseases like rheumatoid arthritis (Shah et al., 2015).

\section{Anti cholestrolemic agent}

Mortality caused by cardiovascular diseases (CVDs) has manifested approximately 17.5 million cases in 2012 and is expected to project a gradual rise to 22.2 million cases by 2030 (Patel et al., 2011). Based on a report by Praveen and coauthors, the endophytic fungi are a poor candidate to produce lovastatin compared to the fungi from soil isolate (Praveen et al., 2014). However, this claim has been denied by Ahmed El-Gendy et al. (2016), Patil et al. (2017) and Kanjana et al. (2019). Lovastatin is a natural statin drug used in CVDs treatment after the compactin failure (Endo, 2010). In general, statins inhibit 3-hydroxy-3methylgutaryl CoA or HMG-CoA reductase in the cholesterol biosynthesis pathway. Statins are the premium prescribed drug to cholesterolemia patients, albeit some of the statins are associated with adverse effects. Patients are commonly suffering from statins intolerance (Arca et al., 2012) or, even worst, the development of atherosclerosis. This event is triggered accordingly by the increase of low-density lipoprotein (LDL), specifically oxidized LDL, which later commences monocyte adhesion and eventually driving to atherosclerotic occasions. Thus, it is crucial to avert LDL oxidization (Patil et al., 2017). Bioactive compounds originated from phenolics are known for their antioxidant and antiinflammatory activity, which represent an excellent potential against CVDs (Deng \& Chow, 2010). The phenolics of natural origin are able to decline the oxidation of lipids, as well as proteins (Ellingsen et al., 2009). Besides, the phenolics also own redox properties and capability in quenching reactive oxygen (Patil et al., 2017). These biological actions are appropriate to protect the human body from arterial stiffening and atherosclerosis. Pbyllosticta spinarum (Wijeratne et al., 2008), Aspergillus luchuensis (Ahmed El-Gendy et al., 2016), Diaporthe arengae (Patil et al., 2017),
Chaetomium globosum, Cladosporium tenuissimum and Penicillium janthinellum (Kanjana et al., 2019) are amongst the endophytic fungi that could reduce the in vitro and in vivo cholesterolemia event. From cypress a coniferous tree or Platycladus orientalis, Wijetrane et al. (2008) has isolated P. spinarum. This endophytic fungus owns tauranin, a sesquiterpene quinone, which functions to inhibit the assimilation of acetate-1-14C into free and esterified cholesterol.

Ahmed El-Gendy et al. (2016) have suggested gene transfer via genome shuffling technique to boost lovastatin production by using marine mangrove endophytic fungus, $A$. luchuensis MERV10. The strain improvement scheme, associated with solid-state fermentation system, has multiplied 32-fold of lovastatin productivity which was 2.11 times higher than the parental culture. According to Patil et al. (2017), D. arengae is another prospective anti-hypercholesterolemic fungus resides in the twig tissue of Terminalia arjuna. It is rich in phenolic compounds such as benzene propionic acid, 3,5-bis (1,1dimethylethyl)-4-hydroxy methyl ester, pterin-6carboxylic acid and 2,6-ditert-butyl-4- phenol. In general, the in vivo study on albino Wistar rats has denoted the cholesterol results displayed by fractionated $D$. arengae extract were relative to standard atorvastatin. It is also worth to mention a work by Kanjana et al. (2019) on three endophytic fungi, specifically C. globosum, C. tenuissimum and P. janthinellum. These fungi were isolated from therapeutic plants i.e., Passiflora foetida, Memecylon edule and Justicia adhatoda, respectively. There are several potential anti cholesterolemic agent available in the ethyl acetate extract, including benzene propionic acid, 3,5-bis (1,1-dimethylethyl)-4-hydroxy methyl ester, pterin-6-carboxylic acid, 2,6-ditert-butyl-4phenol, (Z,Z)-9,12-octadecadienoic acid, nhexadecanoic acid, acetic acid, cinnamyl ester, hexadecanoic acid, methyl ester and tetradecanoic acid. Series of endophytic fungi with their novel compounds, biological activities and original host plants are summarized in Table 1. 
Table 1. Series of novel bioactive compounds with different biological activities isolated from various endophytic fungi.

\begin{tabular}{|c|c|c|c|c|}
\hline Actives & Types of Fungi & Host & Activity & References \\
\hline $\begin{array}{l}\text { Pyrenosines (phomopsinone A, B, C } \\
\text { and D) }\end{array}$ & Phomopsis sp. & Stems of Santolina chamaecyparissus & Antimicrobial & Hussain et al. (2012a) \\
\hline Pyrenosines J, K L and M & Phomopsis sp. & Cistus salvifolius & Antimicrobial & Hussain et al. (2012b) \\
\hline Hydroxyanthraquinones 1 & Coniothyrium sp. & Salsola oppostifolia & Antimicrobial & Sun et al. (2013a) \\
\hline Hydroxyanthraquinones 2 & Coniothyrium sp. & Salsola oppostifolia & Antimicrobial & Sun et al. (2013a) \\
\hline Hydroxyanthraquinones 3 & Coniothyrium sp. & Salsola oppostifolia & Antimicrobial & Sun et al. (2013a) \\
\hline Hydroxyanthraquinones 4 & Coniothyrium sp. & Salsola oppostifolia & Antimicrobial & Sun et al. (2013a) \\
\hline Coniothyrinones A & Coniothyrium sp. & Salsola oppostifolia & Antimicrobial & Sun et al. (2013a) \\
\hline Coniothyrinones B & Coniothyrium sp. & Salsola oppostifolia & Antimicrobial & Sun et al. (2013a) \\
\hline Coniothyrinones $\mathrm{C}$ & Coniothyrium sp. & Salsola oppostifolia & Antimicrobial & Sun et al. (2013a) \\
\hline Coniothyrinones D & Coniothyrium sp. & Salsola oppostifolia & Antimicrobial & Sun et al. (2013a) \\
\hline $\begin{array}{l}\text { 3-hydroxy-5-methoxyhex-5-ene-2,4- } \\
\text { dione }\end{array}$ & Diaporthe sp. ED2 & Orthosiphon stamineus & Antimicrobial & Tong et al. (2017) \\
\hline 3-hydroxypropionic acid & Phomopsis phaseolorum & $\begin{array}{l}\text { Branches of mangrove } \\
\text { Laguncularia racemosa }\end{array}$ & Antimicrobial & $\begin{array}{l}\text { Sebastianes et al. } \\
(2012)\end{array}$ \\
\hline Pestalotiopen A & Pestalotiopsis sp. & $\begin{array}{l}\text { Chinese mangrove Rhizophora } \\
\text { mucronata }\end{array}$ & Antimicrobial & $\begin{array}{l}\text { Hemberger et al. } \\
(2013)\end{array}$ \\
\hline Cristatumin A & $\begin{array}{l}\text { Eurotiumcristatum sp. EN- } \\
220\end{array}$ & Marine alga Sargassum thunbergii & Antimicrobial & Du et al. (2012) \\
\hline Tardioxopiperazine A & $\begin{array}{lll}\text { Eurotium } & \text { cristatum } & \text { sp. } \\
\text { EN-220 } & & \\
\end{array}$ & Marine alga Sargassum thunbergii & Antimicrobial & Du et al. (2012) \\
\hline Isorhodoptilometrin-1-methyl ether & Aspergillus versicolor & $\begin{array}{l}\text { Green alga Halimeda opuntia } \\
\text { internal tissues }\end{array}$ & Antimicrobial & Hawas et al. (2012) \\
\hline Siderin & Aspergillus versicolor & $\begin{array}{l}\text { Green alga Halimeda opuntia } \\
\text { internal tissues }\end{array}$ & Antimicrobial & Hawas et al. (2012) \\
\hline Yicathin B & Aspergillus wentii PT- 1 & Gymnogongrus flabelliformis & Antimicrobial & Sun et al. (2013b) \\
\hline Yicathin C & Aspergillus wentii PT- 1 & Gymnogongrus flabelliformis & Antimicrobial & Sun et al. (2013b) \\
\hline Flavipesins A & Aspergillus flavipes & Acantbus ilicifolius & Antimicrobial & Bai et al. (2015) \\
\hline $\begin{array}{l}\text { 3,1'-didehydro-3[2"(3"',3"'-dimethyl- } \\
\text { prop-2-enyl)-3"-indolylmethylene]-6- } \\
\text { methyl pipera-zine-2,5-dione }\end{array}$ & $\begin{array}{ll}\text { Penicillium } & \text { chrysogenum } \\
\text { MTCC } 5108\end{array}$ & $\begin{array}{l}\text { Leaves of mangrove plant } \\
\text { Porteresia coarctata (Roxb.) }\end{array}$ & Antimicrobial & Devi et al. (2012) \\
\hline 7-methoxymacrosporin & Phoma sp. & Myoporum bontiodes A roots & Antimicrobial & Huang et al. (2017) \\
\hline
\end{tabular}




\begin{tabular}{|c|c|c|c|c|}
\hline Pyrrocidine C & $\begin{array}{l}\text { Lewia infectoria SNB- } \\
\text { GTC2402 }\end{array}$ & Besleria insolita & Antimicrobial & Casella et al. (2013) \\
\hline Biscogniazaphilones A & $\begin{array}{ll}\text { Biscogniauxia } & \text { formosana } \\
\text { BCRC } 33718 & \\
\end{array}$ & Bark of a Cinnamomum sp. & Antimicrobial & Cheng et al. (2012) \\
\hline Biscogniazaphilones B & $\begin{array}{l}\text { Biscogniauxia formosana } \\
\text { BCRC } 33718\end{array}$ & Bark of a Cinnamomum sp. & Antimicrobial & Cheng et al. (2012) \\
\hline $\begin{array}{l}\text { 4-(2,4,7-trioxa-bicyclo[4.1.0]heptan- } \\
\text { 3-yl)-phenol }\end{array}$ & Pestalotiopsis mangifera & Mango tree & Antimicrobial & Subban et al. (2013) \\
\hline $\begin{array}{l}\text { 6-Methyl-1,2,3-trihydroxy-7,8- } \\
\text { cyclohepta-9,12-diene-11-one- } \\
\text { 5,6,7,8-tetralene-7-acetamide }\end{array}$ & Aspergillus sp. & Gloriosa superba & Antimicrobial & Budhiraja et al. (2013) \\
\hline 7,8-dihydonivefuranone $\mathrm{A}$ & Microdiplodia sp. KS 75-1 & Stems of Pinus sp. & Antimicrobial & Shiono et al. (2012) \\
\hline $\begin{array}{l}6(7) \text {-dehydro-8- } \\
\text { hydroxyterrefuranone }\end{array}$ & Microdiplodia sp. KS 75-1 & Stems of Pinus sp. & Antimicrobial & Shiono et al. (2012) \\
\hline 6-hydroxyterrefuranone & Microdiplodia sp. KS 75-1 & Stems of Pinus sp. & Antimicrobial & Shiono et al. (2012) \\
\hline Nivefuranones A & Microdiplodia sp. KS 75-1 & Stems of Pinus sp. & Antimicrobial & Shiono et al. (2012) \\
\hline Crypsporioptide & Cryptosporiopsis sp. & $\begin{array}{l}\text { Shoot tissue of shrub Viburnum } \\
\text { tinus }\end{array}$ & Antimicrobial & Saleem et al. (2013) \\
\hline Dothideomycetide A & Dothideomycete sp. & Tiliacora triandra & Antimicrobial & Senadeera et al. (2012) \\
\hline $\begin{array}{l}\text { 2-Hydroxy-6-methylbenzoic acid (6- } \\
\text { methylsalicylic acid) }\end{array}$ & $\begin{array}{l}\text { Pseudocercospora sp. ESL } \\
02\end{array}$ & Elaeocarpus sylvestris & Antioxidant & $\begin{array}{l}\text { Prihantin \& Tachibana } \\
(2017)\end{array}$ \\
\hline Paclitaxel or taxol & C. capsici & Infected fruit of Capsicum annuиm & Anticancer & Kumaran et al. (2011) \\
\hline Paclitaxel or taxol & Seimatoantlerium tepuiense & Maguireothamnus speciosus & Anticancer & Strobel et al. (1999) \\
\hline Paclitaxel or taxol & Tubercularia sp. & T. mairei & Anticancer & Wang et al. (2000) \\
\hline Paclitaxel or taxol & F. redolens & Himalayan yem plants & Anticancer & Garyali et al. (2013) \\
\hline Camptothecin & E. infrequens & Inner bark of $N$. foetida & Anticancer & Puri et al. (2005) \\
\hline Camptothecin & Strain ZP5SE & Seed of $N$. foetida & Anticancer & Rehman et al. (2008) \\
\hline Camptothecin & Strain XK001 & C. acuminate & Anticancer & Min \& Wang (2009) \\
\hline Camptothecin & Fusarium solani & C. acuminate & Anticancer & Kusari et al. (2009) \\
\hline Camptothecin & Strain 10-OH-CPT & A. dimidiate & Anticancer & Shweta et al. (2010) \\
\hline Vincristine & F. oxysporum & C. roseus & Anticancer & $\begin{array}{l}\text { Guo \& } \\
(1998)\end{array}$ \\
\hline Vincristine and vinblastine & Strain AA-CRL-6 & C. roseus & Anticancer & Kumar et al. (2013) \\
\hline Vincristine and vinblastine & T. radicus & C. roseus & Anticancer & Palem et al. (2015) \\
\hline Podophyllotoxin & Strain PPE5 & Rhizomes of S. peltatum & Anticancer & Eyberger et al. (2006) \\
\hline
\end{tabular}




\begin{tabular}{|c|c|c|c|c|}
\hline Podophyllotoxin & Strain PPE7 & Rhizomes of $S$. peltatum & Anticancer & Eyberger et al. (2006) \\
\hline Podophyllotoxin & T. birsuta & S. hexandrum & Anticancer & Puri et al. (2006) \\
\hline Podophyllotoxin & Alternaria sp. & S. hexandrum & Anticancer & Cao et al. (2007) \\
\hline Podophyllotoxin & F. oxysporum & S. recurva & Anticancer & Kour et al. (2008) \\
\hline Podophyllotoxin & F. solani & Roots of P. hexandrum & Anticancer & Nadeem et al. (2012) \\
\hline cis-4-hydroxymellein & Aspergillus flocculus & Markhamia platycalyx & Anticancer & Tawfike et al. (2019) \\
\hline 5-hydroxymellein & Aspergillus flocculus & Markhamia platycalyx & Anticancer & Tawfike et al. (2019) \\
\hline Diorcinol & Aspergillus flocculus & Markhamia platycalyx & Anticancer & Tawfike et al. (2019) \\
\hline Botryoisocoumarin A & Aspergillus flocculus & Markhamia platycalyx & Anticancer & Tawfike et al. (2019) \\
\hline Mellein & Aspergillus flocculus & Markhamia platycalyx & Anticancer & Tawfike et al. (2019) \\
\hline Unknown & Trichoderma sp. & Stem bark of Terminalia catappa & Anticancer & $\begin{array}{l}\text { Majoumouo et al. } \\
(2020)\end{array}$ \\
\hline $\begin{array}{l}\text { (1R,6S)-3-hydroxy-4-methyl-7- } \\
\text { oxabicyclo[4.1.0]hept-3-ene-2,5- } \\
\text { dione (terreic acid) }\end{array}$ & $\begin{array}{l}\text { Psendocercospora sp. ESL } \\
02\end{array}$ & Elaeocarpus sylvestris & Antioxidant & $\begin{array}{l}\text { Prihantin \& Tachibana } \\
\text { (2017) }\end{array}$ \\
\hline Wentiquinone $\mathrm{C}$ & Aspergillus sp. & Marine brown alga & Antioxidant & Li et al. (2014) \\
\hline $\begin{array}{l}\text { Methyl 4-(3,4- } \\
\text { dihydroxybenzamido)butanoate }\end{array}$ & Aspergillus sp. & Marine brown alga & Antioxidant & Li et al. (2014) \\
\hline Exopolysaccharide As1-1 & Aspergillus sp.Y16 & Leave of Ipomoea pes-caprae (Linn.) & Antioxidant & Chen et al. (2011) \\
\hline $\begin{array}{l}\text { 4,7-dihydroxy-3,9-dimethoxy-1- } \\
\text { methylbenzo[c]chromen-6-one } \\
\text { (graphislactone A) }\end{array}$ & Cephalosporium sp. & $\begin{array}{l}\text { Root of Trachelospermum } \\
\text { jasminoides (Apocynaceae) }\end{array}$ & Antioxidant & Song et al. (2005) \\
\hline Phenylpropanoid amide & Penicillium brasilianum & Root bark of Melia azedarach & Antioxidant & Fill et al. (2010) \\
\hline $\begin{array}{l}\text { 2-(7-hydroxy-5-methyl-1,3-dihydro- } \\
\text { 2-benzofuran-1-yl)benzene-1,3-diol } \\
\text { (pestacin) }\end{array}$ & Pestalotiopsis microspora & Terminalia morobensis & Antioxidant & Harper et al. (2003) \\
\hline $\begin{array}{l}\text { 4,7,7-trimethylbicyclo[2.2.1] heptan- } \\
\text { 3-ol (borneol) }\end{array}$ & Cochliobolus nisikadoi & $\begin{array}{l}\text { Cinnamomum camphora chvar. } \\
\text { Borneol }\end{array}$ & Antioxidant & Chen et al. (2011) \\
\hline $\begin{array}{l}\text { (2R,6aS,12aS)-1,2,6,6a,12,12a- } \\
\text { hexahydro-2-isopropenyl-8,9- } \\
\text { dimethoxychromeno[3,4-b] furo }(2,3- \\
\text { h) chromen-6-one (rotenone) }\end{array}$ & Penicillium sp. & Derris elliptica Benth & Insecticidal & Hu et al. (2005) \\
\hline
\end{tabular}


Bicyclo[4.4.0]deca-1,3,5,7,9-pentaene
Bicyclo[4.4.0]deca-2,4,6,8,10-
Muscodor vitigenus
Paullinia paullinioides
Insecticidal
Daisy et al. (2012)

pentaene (naphthalene)

(E)-3-methoxy-2-propenyl-5-(2'-

carbomethoxy-4'-6'-

dimethoxybenzoyl)-4-pyrone

methylfunicone)

5-hydroxy-2- (1'-oxo-5'-methyl-4'-

hexenyl) benzofuran and 5-hydroxy-

2-(1'-hydroxy-5'-methyl-4'-

Talaromyces pinophilus Arbutus unedo

Insecticidal

Vinale et al. (2017)

hexenyl)benzofuran

(2E)-5-[(3S,4S,4aR, 6aS, 12bS,12cS)-3-

Hydroxy-4,12b,12c-trimethyl-9,10-

bis(3-methyl-2-buten-1-yl)-

$1,2,3,4,4 a, 5,6,6 a, 7,12,12 b, 12 c-$

Nodulisporium sp

Bontia daphnoides

Insecticidal

Aly et al. (2011)

dodecahydrobenzo[6,7]indeno[1,2-

b]indol-4-yl]-2-methyl-2-pentenoic acid (nodulisporic acid $A$ )

2,6-di-tert-butyl-p-cresol

L-783,281 (demethyl-asterriquinone

B1)

Unidentified

Gaultheria procumbens L

Insecticidal

Findlay et al. (1997)

$\mathrm{N}$-acetylgalactosamine (lectin)

Aspergillus sp., Salvadora oleoides Decne

Antidiabetic

Dhankhar et al. (2013)

Pseudomassaria sp.

Unknown

Antidiabetic

Zhang et al. (1999)

Colutellin A

Alternaria sp.

Viscum album

Antidiabetic

Govindappa et al. (2015)

\begin{tabular}{|c|c|c|c|c|}
\hline Colutellin A & Colletotrichum dematium & Pteromischum sp. & Immunosuppressive & Rüegger et al. (1976) \\
\hline Subglutinol A & Fusarium subglutinans & Tripterygium wilfordii & Immunosuppressive & Lee et al. (1995) \\
\hline Subglutinol B & Fusarium subglutinans & Tripterygium wilfordii & Immunosuppressive & Lee et al. (1995) \\
\hline Unknown & Talaromyces wortmannii & Aloe vera & Anti-inflammatory & Pretsch et al. (2014) \\
\hline Mutolide & Lepidosphaeria sp. & Horse dung & $\begin{array}{l}\text { Anti-inflammatory, } \\
\text { Anti-arthritis }\end{array}$ & Shah et al. (2015) \\
\hline Lovastatin & $\begin{array}{ll}\text { Aspergillus } & \text { luchuensis } \\
\text { MERV10 } & \\
\end{array}$ & Marine mangrove & Anti cholesterol & $\begin{array}{l}\text { Ahmed El-Gendy et al. } \\
(2016)\end{array}$ \\
\hline Benzene propionic acid & Diaporthe arengae & Twig tissue of Terminalia arjuna & Anti cholesterol & Patil et al. (2017) \\
\hline $\begin{array}{l}\text { 3, 5-bis (1,1-dimethylethyl)-4- } \\
\text { hydroxy methyl ester }\end{array}$ & Diaporthe arengae & Twig tissue of Terminalia arjuna & Anti cholesterol & Patil et al. (2017) \\
\hline Pterin-6-carboxylic acid & Diaporthe arengae & Twig tissue of Terminalia arjuna & Anti cholesterol & Patil et al. (2017) \\
\hline
\end{tabular}




\begin{tabular}{|c|c|c|c|c|}
\hline 2,6-ditert-butyl-4- phenol & Diaporthe arengae & Twig tissue of Terminalia arjuna & Anti cholesterol & Patil et al. (2017) \\
\hline $\begin{array}{l}(\mathrm{Z}, \mathrm{Z})-9,12 \text {-octadecadienoic acid, n- } \\
\text { hexadecanoic acid, acetic acid, } \\
\text { cinnamyl ester }\end{array}$ & Chaetomium globosum & Passiflora foetida & Anti cholesterol & Kanjana et al. (2019) \\
\hline $\begin{array}{l}\text { Hexadecanoic acid, methyl ester, } \\
(\mathrm{Z}, \mathrm{Z})-9,12 \text {-octadecadienoic acid }\end{array}$ & Cladosporium tenuissimum & Memecylon edule & Anti cholesterol & Kanjana et al. (2019) \\
\hline $\begin{array}{l}\text { Tetradecanoic acid, (Z,Z)-9,12- } \\
\text { octadecadienoic acid, n-hexadecanoic } \\
\text { acid, hexadecanoic acid, methyl ester }\end{array}$ & Penicillium janthinellum & Justicia adhatoda & Anti cholesterol & Kanjana et al. (2019) \\
\hline Tauranin & Pbyllosticta spinarum & Platycladus orientalis & Anti cholesterol & Wijetrane et al. (2008) \\
\hline
\end{tabular}




\section{Future prospects and conclusions}

Exploring the endophytic fungi-derived bioactive compounds is not without challenge, albeit it could lead to a discovery of novel compounds with various therapeutic benefits, including a resistance mechanism to counteract pathogenic infiltration. It is believed that secondary metabolites synthesized from endophytic microbes offer a competitive option in overcoming the drug resistance issues by bacteria. Therefore, researchers need to improve and develop the isolation method, rapid genomic data extraction and sequence pairing, which will assist in identifying the types of endophytes as well as their diversity and therapeutic benefit. The toxicity clarification of the identified drug, either on humans, animals, or the environment, is also essential in meeting a highly effective drug for multiple diseases nowadays. Another challenge that needs to be taken into account is the largescale production of the targeted drugs since there are a number of genes involved in the biosynthesis pathway. The exploitation of these challenges holds a great promise for human's health. There is an increasing concern on applying endophyticbased natural products in the industrial sector. In this review, some of the reported compounds such as paclitaxel or taxol, camptothecin, vinblastine, vincristine and statin have been penetrated in the market for pharmaceutical and medicinal uses. A triumphant impact of these endophytic fungal-based drugs has given a positive indicator for the researchers in finding a novel compound, which may benefit other industrial sectors, including agriculture, food safety and cosmetics.

\section{ACKNOWLEDGEMENTS}

We would like to thank Malaysia Ministry of Higher Education (MOHE) for supporting the project of endophytic fungi (PRGS/1/2019/STG05/UNIKL/02/1).

\section{CONFLICT OF INTERESTS}

The authors have declared that no conflict of interest exists.

\section{REFERENCES}

Ahmed El-Gendy, M. M. A., Al-Zahrani, H. A. A., \& El-Bondkly, A. M. A. 2016. Genome shuffling of mangrove endophytic Asperiillus luchuensis MERV10 for improving the cholesterol-lowering agent lovastatin under solid state fermentation. Mycobiology 44(3): 171-179.

Ali, S. F., Binienda, Z. K., \& Imam, S. Z. 2011. Molecular aspects of dopaminergic neurodegeneration: Gene-environment interaction in Parkin dysfunction. International Journal of Environmental Research and Public Health 8(12): 4702-4713.

Aly, A. H., Debbab, A., \& Proksch, P. 2011. Fungal endophytes: Unique plant inhabitants with great promises. Applied Microbiology and Biotechnology 90(6): 1829-1845.

Arca, M., Pigna, G., \& Favoccia, C. 2012. Management of statinintolerant patient. Panminerva Medica 54(2): 105-18.

Bai, Z. Q., Lin, X., Wang, J., Zhou, X., Liu, J., Yang, B., \& Liu, Y. 2015. New meroterpenoids from the endophytic fungus Aspergillus flavipes AIL8 derived from the mangrove plant Acanthus ilicifolius. Marine Drugs 13(1): 237-248.

Bray, F., Ferlay, J., Soerjomataram, I., Siegel, R. L., Torre, L. A., \& Jemal, A. 2018. Global cancer statistics 2018: GLOBOCAN estimates of incidence and mortality worldwide for 36 cancers in 185 countries. CA: A Cancer Journal for Clinicians 68(6): 394-424.

Budhiraja, A., Nepali, K., Sapra, S., Gupta, S., Kumar, S., \& Dhar, K.L. 2013. Bioactive metabolites from an endophytic fungus of Aspergillus species isolated from seeds of Gloriosa superba Linn. Medical Chemistry Research 22:323-329.

Cao, L., Huang, J., \& Li, J. 2007. Fermentation conditions of Sinopodophyllum hexandrum endophytic fungus on production of podophyllotoxin. Food and Fermentation Industries 33: 28 32.

Casella, T. M., Eparvier, V., Mandavid, H., Bendelac, A., Odonne, G., \& Dayan, L. 2013. Antimicrobial and cytotoxic secondary metabolites from tropical leaf endophytes: isolation of antibacterial agent pyrrocidine $\mathrm{C}$ from Lewiainfectoria SNB-GTC2402. Phytochemistry 96: 370-377.

Chen, Y., Mao, W., Tao, H., Zhu, W., Qi, X., Chen, Y., \& Wang, C. 2011. Structural characterization and antioxidant properties of an exopolysaccharide produced by the mangrove endophytic fungus Aspergillus sp. Y16. Bioresource Technology 102(17): 8179-8184.

Cheng, M. J., Wu, M. D., Yanai, H., Su, Y. S., Chen, I. S., Yuan, G. F., Hsieh, S. Y., \& Chen, J. J. 2012. Secondary metabolites from the endophytic fungus Biscogniauxia formosana and their antimycobacterial activity. Phytochemistry Letters 5(3): 467 472.

Choudhary, M., Kumar, V., Malhotra H., \& Singh, S. 2015. Medicinal plants with potential anti-arthritic activity. Journal of Intercultural Ethnopharmacology 4(2): 147-179.

Chu, C., Xu, J., Cheng, D., Li, X., Tong, S., Yan, J. \& Li, Q. 2014. Anti-proliferative and breast tumor MCF-7 cells. Molecules 19: 4941-4955.

Daisy, B. H., Strobel, G. A., Castillo, U., Ezra, D., Sears, J., Weaver, D. K., \& Runyon, J. B. 2002. Naphthalene, an insect 
repellent, is produced by Muscodor vitigenus, a novel endophytic fungus. Microbiology 148(11): 3737-3741.

De Stefano, S., Nicoletti, R., Milone, A., \& Zambardino, S. 1999. 3-O-Methylfunicone, a fungitoxic metabolite produced by the fungus Penicillium pinophilum. Phytochemistry 52(8): 13991401.

Deng, R., \& Chow, T. J. 2010. Hypolipidemic, antioxidant, and antiinflammatory activities of Microalgae spirulina. Cardiovascular Therapeutics 28(4): e33-e45.

Devi, P., Rodrigues, C., Naik, C. G., \& D'Souza, L. 2012. Isolation and characterization of antibacterial compound from a mangrove-endophytic fungus, Penicillium chrysogenum MTCC 5108. Indian Journal Microbiology 52: 617-623.

Dewi, R. T., Tachibana, S., Itoh, K., \& Ilyas, M. 2012. Isolation of antioxidant compounds from Aspergillus terreus LS01. Journal of Microbial and Biochemical Technology 4(1): 010-014.

Dhankhar, S., Dhankhar, S., \& Yadav, J. P. 2013. Investigations towards new antidiabetic drugs from fungal endophytes associated with Salvadora oleoides Decne. Journal of Medicinal Chemistry 9(4): 624-632.

Du, F. -Y., Li, X. -M., Li, C. -S., Shang, Z., \& Wang, B. -G. 2012. Cristatumins A-D, new indole alkaloids from the marinederived endophytic fungus Eurotium cristatum EN-220. Bioorganic and Medicinal Chemistry Letters 22(2012): 4650-4653.

Ellingsen, I., Seljeflot, I., Arnesen, H., \& Tonstad, S. 2009. Vitamin $\mathrm{C}$ consumption is associated with less progression in carotid intima media thickness in elderly men: A 3-year intervention study. Nutrition, Metabolism and Cardiovascular Diseases 19: 814.

El-Sayed, A. S. A., El-Sayed, M. T., Rady, A. M., Zein, N., Enan, G., Shindia, A., El-Hefnawy, S., Sitohy, M., \& Sitohy, B. 2020. Exploiting the biosynthetic potency of taxol from fungal endophytes of conifers plants; Genome mining and metabolic manipulation. Molecules 25(13): 3000.

Endo, A. 2010. A historical perspective on the discovery of statins. Proceedings of the Japan Academy, Ser. B, Physical and Biological Sciences 86(5): 484-493.

Eyberger, A. L., Dondapati, R., \& Porter, J. R. 2006. Endophyte fungal isolates from Podophyllum peltatum produce podophyllotoxin. Journal of Natural Products 69: 1121-1124.

Faeth, S. H., \& Fagan, W. F. 2002. Fungal endophytes: Common host plant symbionts but uncommon mutualists. Integrative and Comparative Biology 42(2): 360-368.

Findlay, J. A., Buthelezi, S., Li, G., Seveck, M., \& Miller, J. D. 1997. Insect toxins from an endophytic fungus from wintergreen. Journal of Natural Products 60(11): 1214-1215.

Foley, E. A., \& Kapoor, T. M. 2013. Microtubule attachment and spindle assembly checkpoint signalling at the kinetochore. Nature Reviens Molecular Cell Biology 14: 25-37.

Garyali, S., Kumar, A., \& Reddy, M. S. 2013. Taxol production by and endophytic fungus, Fusarium redolens, isolated from Himalayan Yew. Journal of Microbiology and Biotechnology 23(10): 1372-1380.

Gouda, S., Das, G., Sen, S. K., Shin, H. -S., \& Patra, J. K. 2016. Endophytes: a treasure house of bioactive compounds of medicinal importance. Frontiers in Microbiology 7: 1538.

Govindappa, M., Sadananda, T. S., Channabasava Ramachandra, Y. L., Chandrappa, C. P., Padmalatha, R. S., \& Prasad, S. K. 2015. In vitro and in vivo antidiabetic activity of lectin (Nacetylgalactosamine, $64 \mathrm{kDa}$ ) isolated from endophytic fungi, Alternaria species from Viscum album on alloxan induced diabetic rats. Integrative Obesity and Diabetes 1(1): 1119.

Guo, B., \& Kunming, L.H. 1998. A middle vinblastine fungi isolated. Journal of Yunnan University 20: 214-215.

Guo, C. J., Sun, W. W., Bruno, K. S., \& Wang, C. C. 2014. Molecular genetic characterization of terreic acid pathway in Aspergillus terreus. Organic Letters 16(20): 5250-5253.
Hardoim, P. R., van Overbeek, L. S., \& van Elsas, J. D. 2008. Properties of bacterial endophytes and their proposed role in plant growth. Trends in Microbiology 16: 463-471.

Harper, J. K., Arif, A. M., Ford, E. J., Strobel, G. A., Porco, J. A., Tomer, D. P., \& Grant, D. M. 2003. Pestacin: a 1, 3-dihydro isobenzofuran from Pestalotiopsis microspora possessing antioxidant and antimycotic activities. Tetrabedron 59(14): 2471-2476.

Hawas, U. W., El-Beih, A. A., \& El-Halawany, A. M. 2012. Bioactive anthraquinones from endophytic fungus Aspergillusversicolor isolated from red sea alga. Archives of Pharmacal Research 35: 1749-1756.

Hawksworth, D. L. 1991. The fungal dimension of biodiversity, magnitude, significance and conservation. Mycological Research 95: 641-655.

Hemberger, Y., Xu, J., Wray, V., Proksch, P., Wu, J., \& Bringmann, G. 2013. Pestalotiopens A and B: stereochemically challenging flexible sesquiterpene-cyclopaldic acid hybrids from Pestalotiopsis sp. Chemistry-A European Journal 19: 15556-15564.

Horwitz, S. B., Lothstein, L., Manfredi, J. J., Mellado, W., Parness, J., Roy, S. N., Schiff, P. B., Sorbara, L., \& Zeheb, R . 1986. Taxol: Mechanisms of action and resistance. Annals of the New York Academy of Sciences 466: 733-744.

Hu, M. Y., Zhong, G. H., Sun, Z. T., Sh, G., Liu, H. M., \& Liu, X. Q. 2005. Insecticidal activities of secondary metabolites of endophytic Pencillium sp. in Derris elliptica Benth. Journal of Applied Entomology 129(8): 413-417.

Huang, S., Xu, J., Li, F., Zhou, D., Xu, L., \& Li, C. 2017. Identification and antifungal activity of metabolites from the mangrove fungus Phoma sp. L28. Chemistry of Natural Compounds 53(2): 237-240.

Hussain, H., Ahmed, I., Schulz, B., Draeger, S., \& Krohn, K. 2012b. Pyrenocines J-M: Four new pyrenocines from the endophytic fungus, Phomopsis sp. Fitoterapia 83(3): 523-526.

Hussain, H., Krohn, K., Ahmed, I., Draeger, S., Schulz, B., Di Pietro, S., \& Pescitelli, G. 2012a. Phomopsinones A-D: Four new pyrenocines from endophytic fungus Phomopsis sp. European Journal of Organic Chemistry 2012(9): 1783-1789.

Hyde, K. D., \& Soytong, K. 2008. The fungal endophyte dilemma. Fungal Diversity 33:163-173.

Kanjana, M., Kanimozhi, G., Udayakumar, R., \& Panneerselvam, A. 2019. GC-MS analysis of bioactive compounds of endophytic fungi Chaetomium globosum, Cladosporium tenuissimum and Penicillium jantbinellum. Journal of Biomedical and Pharmaceutical Sciences 2(1): 2019.

Khameneh, B., Iranshahy, M., Soheili, V., \& Bazzaz, B. S. F. 2019. Review on plant antimicrobials: a mechanistic viewpoint. Antimicrobial Resistance \& Infection Control 8: 118.

Kour, A., Shawl, A. S., Rehman, S., Sultan, P., Qazi, P. H., Suden, P., Khajuria, R. K., \& Verma, V. 2008. Isolation and identification of an endophytic strain of Fusarium oxysporum producing podophyllotoxin from Juniperus recurva. World Journal of Microbiology and Biotechnology 24: 1115-1121.

Kumar, A., Patil, D., Rajamohanan, P.R., \& Ahmad, A. 2013. Isolation, purification and characterization of vinblastine and vincristine from endophytic fungus Fusarium oxysporum isolated from Catharanthus roseus. PLOS ONE 8(9): e71805.

Kumar, D. S. S., Lau, C. S., Wan, J. M. F., Yang, D., \& Hyde, K. D. 2005. Immunomodulatory compounds from Pestalotiopsis leucothës, an endophytic fungus from Tripterygium wilfordii. Life Sciences 78(2): 147-156.

Kumaran, R.S., Jung, H., \& Kim, H.J. 2011. In vitro screening of taxol, an anticancer drug produced by the fungus, Colletotrichum capsici. Engineering in Life Sciences 11(3): 264-271.

Kusari, S., Zuhlke, S., \& Spiteller, M. 2009. An endophytic fungus from Camptotheca acuminata that produces camptothecin and analogues. Journal of Natural Products 72: 2-7. 
Lee, J. C., Lobkovsky, E., Pliam, N. B., Stroble, G. A., \& Clardy, J. 1995. Subglutinol A and B: immunosuppressive compounds from the endophytic fungus Fusarium subglutinans. The Journal of Organic Chemistry 60: 7076-7077.

Li, X., Li, X. M., Xu, G. M., Li, C. S., \& Wang, B. G. 2014. Antioxidant metabolites from marine alga-derived fungus Aspergillus wentii EN-48. Phytochemistry Letters 7: 120-123.

Lu, L., He, J., Yu, X., Li, G., \& Zhang, X. 2006. Studies on isolation and identification of endophytic fungi strain SC13 from pharmaceutical plant Sabina vulgaris Ant. and metabolites. Acta Agriculturae Boreali-occidentalis Sinica 15: 85-89.

Maghrani, M., Zeggwagh, N., Michel, J., \& Eddouks, M. 2005. Antihypertensive effect of Lepidium sativum L. in spontaneously hypertensive rats. Journal of Ethnopharmacology 100(102): 193-197.

Majoumouo, M. S., Tincho, M. B., Kouipou Toghueo, R. M., Morris, T., Hiss, D. C., Boyom, F. F., \& Mandal, C. 2020. Cytotoxicity potential of endophytic fungi extracts from Terminalia catappa against human cervical cancer cells. Journal of Toxicology 2020: 1-9.

Min, C., \& Wang, X. 2009. Isolation and identification of the 10 hydroxycamptothecin-producing endophytic fungi from Camptotheca acuminata Decne. Acta Botanica BorealiOccidentalia Sinica 29:0614-0617.

Nadeem, M., Ram, M., Alam, P., Ahmad, M.M., Mohammad, A., Al-Qurainy, F., Khan, S., \& Abdin, M.Z. 2012. Fusarium solani, P1, a new endophytic podophyllotoxin-producing fungus from roots of Podophyllum hexandrum. African Journal of Microbiology Research 6:2493-2499.

Othman, L., Sleiman, A., \& Abdel-Massih, R. M. (2019). Antimicrobial activity of polyphenols and alkaloids in middle eastern plants. Frontiers in Microbiology 10: 911.

Oukala, N., Aissat K., \& Pastor, V. 2021. Bacterial endophytes: The hidden actor in plant immune responses against biotic stress. Plants 10(5): 1012.

Padmanabha, B., Chandrashekar, M., Ramesha, B., Gowda, H., Gunaga, R., Suhas, S Vasudeva, R., Ganeshaiah, K. N., \& Shaanker, R. 2006. Patterns of accumulation of camptothecin, an anti-cancer alkaloid in Nothapodytes nimmoniana Graham., in the Western Ghats, India: Implications for identifying highyielding sources of the alkaloid. Current Science 90(1): 95-100.

Palem, P. P. C., Kuriakose, G. C., \& Jayabaskaran, C. 2015. An endophytic fungus, Talaromyces radicus, isolated from Catharanthus roseus, produces vincristine and vinblastine, which induce apoptotic cell death. PLOS ONE 10(12): e0144476.

Patel, V., Chatterji, S., Chisholm, D., Ebrahim, S., Gopalakrishna, G., Mathers, C., Mohan V., Prabhakaran, D., Ravindran, R. D., \& Reddy, K. S. 2011. Chronic diseases and injuries in India. The Lancet 377(9763): 413-428.

Patil, M., Patil, R., Mohammad, S., \& Maheshwari, V. 2017. Bioactivities of phenolics-rich fraction from Diaporthe arengae TATW2, an endophytic fungus from Terminalia arjuna (Roxb.). Biocatalysis and Agricultural Biotechnology 10: 396-402.

Prabavathy, D., \& Vallinachiyar, C. 2013. Antimicrobial and antidiabetic activity of endophytic fungi isolated from Adathoda beddomei. International Journal of Pharmacy and Pharmaceutical Sciences 5(3): 780-783.

Praveen, V., Bhargavi, S., \& Savitha, J. 2014. Endophytic fungi: A poor candidate for the production of lovastatin. British Microbiology Research Journal 4(12): 1511-1520.

Pretsch, A., Nagl, M., Schwendinger, K., Kreiseder, B., Wiederstein, M., \& Pretsch, D. 2014. Antimicrobial and antiinflammatory activities of endophytic fungi Talaromyces wortmannii extracts against acne-inducing bacteria. PLOS ONE 9(6): e97929.
Prihantini, A. I., \& Tachibana, S. 2017. Antioxidant compounds produced by Pseudocercospora sp. ESL 02, an endophytic fungus isolated from Elaeocarpus sylvestris. Asian Pacific Journal of Tropical Biomedicine 7(2): 110-115.

Pu, X., Qu, X., Chen, F., Bao, J., Zhang, G. \& Luo, Y. 2013. Camptothecin-producing endophytic fungus Trichoderma atroviride LY357: isolation, identification, and fermentation conditions optimization for camptothecin production. Applied Microbiology and Biotechnology 97: 9365-9375.

Puri, S. C., Amna, T., Khajuria, A., Gupta, A., Arora, R., Spiteller, M., \& Qazi, G. N. 2007. Immunomodulatory activity of an extract of the novel fungal endophyte Entrophospora infrequens isolated from Nothapodytes foetida (Wight) Sleumer. Acta Microbiologica et Immunologica Hungarica 54(3): 237-260.

Puri, S. C., Nazir, A., \& Chawla, R. 2006. The endophytic fungus Trametes birsuta as a novel alternative source of podophyllotoxin and related aryl tetralin lignans. Journal of Biotechnology 122:494-510.

Puri, S. C., Verma, V., Amna, T., Qazi, G. N., \& Spiteller, M. 2005. An endophytic fungus from Nothapodytes foetida that produces camptothecin. Journal of Natural Products 68:17171719.

Rehman, S., Shawl, A.S., Kour, A., Andrabi, R., Sudan, P., Sultan, P., Verma, V., \& Qazi, G.N. 2008. An endophytic Neurospora sp. from Nothapodytes foetida producing camptothecin. Applied Biochemistry and Microbiology 44: $203-$ 209.

Rodriguez, R. J., White Jr, J. F., Arnold, A. E., \& Redman, R. S. 2009. Fungal endophytes: diversity and functional roles. New Phytologist 182(2): 314-330.

Rüegger, A., Kuhn, M., Lichti, H., Loosli, H. R., Huguenin, R., Quiquerez, C., \& Wartburg, A. V. 1976. Cyclosporin A, an immunosuppressive wirksamer peptidmetabolite aus Trichoderma Polysporum (Link ex Pers.). Rifai Helvetica Chimica Acta 59: 1075-1092.

Saleem, M., Tousif, M.I., Riaz, N., Ahmed, I., Schulz, B., Ashraf, M., \& Krohn, K. 2013. Cryptosporioptide: A bioactive polyketide produced by an endophytic fungus Cryptosporiopsis sp. Phytochemistry 93: 199-202.

Schiff, P. B., Fant, J., \& Horwitz, S. B. 1979. Promotion of microtubule assembly in vitro by taxol. Nature 277: 665-667.

Sebastianes, F. L. S., Cabedo, N., Aouad, N. E., Valente, A. M. M. P., Lacava, P. T., Azevedo, J. L., Pizzirani-Kleiner, A. A., \& Cortes, D. 2012. 3-Hydroxypropionic acid as an antibacterial agent from endophytic fungi Diaporthe phaseolorum. Current Microbiology 65(5): 622-632.

Senadeera, S. P. D., Wiyakrutta, S., Mahidol, C., Ruchirawat, S., \& Kittakoop, P. 2012. A novel tricyclic polyketide and its biosynthetic precursor azaphilone derivatives from the endophytic fungus Dotbideomycete sp. Organic \& Biomolecular Chemistry 10(35): 7220.

Shah, M., Deshmukh, S. K., Shilpa, A., Verekar, Gohil, A., Kate, A. S., Rekha, V., \& Almeida, A. K. 2015. Anti-inflammatory properties of mutolide isolated from the fungus Lepidosphaeria species (PM0651419). Springer Plus 4: 706.

Sharma, A., Malholtra, B., Kharkwal, H., Kulkarni, G. T., \& Kaushik, N. 2020. Therapeutic agents from endophytes harbored in Asian medicinal plants. Phytochemistry Reviews 19(3): 691-720.

Shiono, Y., Hatakeyama, T., Murayama, T., \& Koseki, T. 2012. Polyketide metabolites from the endophytic fungus Microdiplodia sp. KS 75-1. Natural Product Communications 7: 1065-1068.

Shwab, E. K., \& Keller, N. P. 2008. Regulation of secondary metabolite production in filamentous ascomycetes. Mycological Research 112: 225-230.

Shweta, S., Zuehlke, S., Ramesha, B.., Priti, V., Mohana Kunar, K.P., Ravikanth, G., Spiteller, M., Vasudeva, R., \& 
Shaanker, R.U. 2010. Endophytic fungal strains of Fusarium solani, from Apodytes dimidiata E. Mey. ex Arn (Icacinaceae) produce camptothecin, 10hydroxycamptothecin and 9-methoxycamptothecin. Phytochemistry 71(1): 117-122.

Singh, B., \& Kaur, A. 2016. Antidiabetic potential of a peptide isolated from an endophytic Aspergillus awamori. Journal of Applied Microbology 120(2): 301-311.

Song, Y. C., Huang, W. Y., Sun, C., Wang, F. W., \& Tan, R. X. 2005. Characterization of graphislactone $A$ as the antioxidant and free radical-scavenging substance from the culture of Cephalosporium sp. IFB-E001, an endophytic fungus in Trachelospermum jasminoides. Biological and Pharmaceutical Bulletin 28(3): 506-509.

Stierle, A., Strobel, G., \& Stierle, D. 1993. Taxol and taxane production by Taxomyces andreanae, an endophytic fungus of Pacific yew. Science 260(5105): 214-6.

Stierle, A., Strobel, G., Stierle, D., Grothaus, P., \& Bignami, G. 1995. The search for a taxol producing microorganism among the endophytic fungi of the Pacific yew, Taxus brevifolia. Journal of Natural Products 58: 1315-1324.

Strobel, G. A. 2003. Endophytes as sources of bioactive products. Microbes and Infection 5: 535-544.

Strobel, G. A.., Torczynski, R., \& Bollon, A. 1997. Acremonium sp. - a leucinostatin A producing endophyte of European yew (Taxus baccata). Plant Science 128: 97-108.

Strobel, G., \& Daisy, B. 2003. Bioprospecting for microbial endophytes and their natural products. Microbiology and Molecular Biology Reviews 67: 491-502.

Strobel, G., Yang, X., Sears, J., Kramer, R., Sidhu, R. S., \& Hess, W. M. 1996. Taxol from Pestalotiopsis microspora, and endophytic fungus of Taxus wallachiana. Microbiology 142: 435-440.

Subban, K., Subramani, R., \& Johnpaul, M. 2013. A novel antibacterial and antifungal phenolic compound from the endophytic fungus Pestalotiopsis mangiferae. Natural Product Research 27: 1445-1449.

Sudakin, D. L., Stone, D. L., \& Power, L. 2011. Naphthalene mothballs: Emerging and recurring issues and their relevance to environmental health. Current Topics in Toxicology 7: 13-19.

Sun, P., Huo, J., Kurtan, T., Mandi, A., Antus, S., \& Tang, H. 2013a. Structural and stereochemical studies of hydroxyanthraquinone derivatives from the endophytic fungus Coniothyrium sp. Chirality 25: 141-148.

Sun, R. -R., Miao, F. -P., Zhang, J., Wang, G., Yin, X. -L., \& Ji, N. -Y. 2013b. Three new xanthone derivatives from an algicolous isolate of Aspergillus wentii. Magnetic Resonance in Chemistry 51(1): 65-68.

Sung, H., Ferlay, J., Siegel, R. L., Laversanne, M., Soerjomataram, I., Jemal, A., \& Bray, F. 2021. Global cancer statistics 2020: GLOBOCAN estimates of incidence and mortality worldwide for 36 cancers in 185 countries. CA: A Cancer Journal for Clinicians 71(3): 209-249.

Tawfike, A. F., Romli, M., Clements, C., Abbott, G., Young, L., Schumacher, M., Diederich, M., Farag, M., \& Edrada-Ebel, R. 2019. Isolation of anticancer and anti-trypanosome secondary metabolites from the endophytic fungus Aspergillus flocculus via bioactivity guided isolation and MS based metabolomics. Journal of Chromatography B 1106-1107: $71-83$.

Thomas, C. J., Rahier, N. J., \& Hecht, S. M. 2004. Camptothecin: current perspectives. Bioorganic and Medicinal Chemistry 12: 1585-1604.

Tong, W. Y., Leong, C. R., Tan, W. N., Khairuddean, M., Zakaria, L., \& Ibrahim, D. 2017. Endophytic Diaporthe sp. ED2 produces a novel anti-candidal ketone derivative. Journal of Microbiology and Biotechnology 27(6): 1065-1070.
Tung, C. Y., Yang, D. B., \& Gou, M. 2002. A Preliminary Study on the Condition of the Culture and Isolate of Endophytic Fungus producing Vincristine. Journal of Chuxiong Normal University 6:39-41.

Ushasri, R., \& Anusha, R. 2015. In vitro anti-diabetic activity of ethanolic and acetone extracts of endophytic fungi Syncephalastrum racemosum isolated from the seaweed Gracilaria corticata by alpha-amylase inhibition assay method. International Journal of Current Microbiology and Applied Sciences 4(1): 254-259.

Verma, V. C., Singh, S. K., \& Kharwar, R. N. 2012. Histological investigation of fungal endophytes in healthy tissues of Azadirachta indica A. Juss. Agricultural Science Journal Science 46: 229-237.

Vinale, F., Nicoletti, R., Lacatena, F., Marra, R., Sacco, A., Lombardi, N., \& Woo, S. L. 2017. Secondary metabolites from the endophytic fungus Talaromyces pinophilus. Natural Product Research 31(15): 1778-1785.

Wang, J., Li, G., Lu, H., Zheng, Z., Huang, Y., \& Su, W. 2000. Taxol from Tubercularia sp. strain TF5, an endophytic fungus of Taxus mairei. FEMS Microbiology Letters 193(2): 249-253.

Wani, M. C., \& Horwitz, S. B. 2014. Nature as a remarkable chemist: a personal story of the discovery and development of taxol. Anti-Cancer Drugs 25(4): 482-487.

Waqas, M., Khan, A. L., Kamran, M., Hamayun, M., Kang, S. M., Kim, Y-H., \& Lee, I-J. 2012. Endophytic fungi produce gibberellins and indoleacetic acid and promotes host-plant growth during stress. Molecules 17: 10754-10773.

Waters, J. C., Chen, R. H., Murray, A. W., \& Salmon, E. D. 1998. Localization of $\mathrm{Mad} 2$ to kinetochores depends on microtubule attachment, not tension. The Journal of Cell Biology 141(5): 1181-1191.

Weaver, B. A. 2014. How taxol/paclitaxel kills cancer cells. Molecular Biology of the Cell 25(18): 2677-2681.

Wijeratne, E. M. K., Paranagama, P. A., Marron, M. T., Gunatilaka, M. K., Arnold, A. E., \& Gunatilaka, A. A. L. 2008. Sesquiterpene quinones and related metabolites from Phyllosticta spinarum, a fungal strain endophytic in Platycladus orientalis, of the Sonoran desert. Journal of Natural Products 71: 218-222.

Xiao, W., Luo, J., Jain, T., Riggs, J. W., Tseng, H. P., Henderson, P. T., Cherry, S. R., Rowland, D., \& Lam, K. S. 2012. Biodistribution and pharmacokinetics of a telodendrimer micellar paclitaxel nanoformulation in a mouse xenograft model of ovarian cancer. International Journal of Nanomedicine 7:1587-97.

Yang, X., Guo, S., Zhang, L., \& Shao, H. 2003. Selection of producing podophyllotoxin endophytic fungi from podophyllin plant. Natural Product Research and Development 15: 419-422.

Young, D. H., Michelotti, E. J., Sivendell, C. S., \& Krauss, N. E. 1992. Antifungal properties of taxol and various analogues. Experientia 48:882-885

Yu, H., Zhang, L., Li, L., Zheng, C., Guo, L., Li, W., Sun, P., \& Qin, L. 2010. Recent developments and future prospects of antimicrobial metabolites produced by endophytes. Microbiological Research 165: 437-449.

Zhang, B., Salituro, G., Szalkowski, D., Li Z., Zhang, Y., \& Royo, I. 1999. Discovery of small molecule insulin mimetic with antidiabetic activity in mice. Science 284(5416): 974-981.

Zhang, L. B., Gou, L. H., \& Zeng, S. V. 2000. Preliminary study in the isolation of endophytic fungus of Catharanthus roseus and its fermentation to produce product of therapeutic value. Chinese Traditional and Herbal Drugs 11: 805-807.

Zhang, L., \& Demain, A. L. 2005. Natural products: Drug discovery and therapeutic medicine. Totowa: Humana Press. 